\title{
UNIVERSITY EDUCATION \\ IN THE FRENCH REPUBLIC: STRUCTURE AND LEGAL FRAMEWORK
}

\author{
Alla Durdas \\ ORCID iD 0000-0001-6456-6108 \\ PhD candidate of the Department of Theory and History of Pedagogy, \\ Pedagogical Institute, Borys Grinchenko Kyiv University, \\ 13-b Tymoshenka Str., 04212 Kyiv, Ukraine, \\ a.durdas@kubg.edu.ua \\ https://doi.org/10.28925/2518-7635.2019.4.7
}

\section{ABSTRACT}

The article deals with the complex and multistage system of higher education of the French Republic. The structural features of higher education in France, its complex and multi-stage system has been considered. Attention is drawn to the role of the state in the field of higher education in France. The importance of the development of education for the national development of the country and civilization as a whole has been stressed. A strong centralized presence and role of the state in the field of education in France has been noted, in particular in the organization of the educational process and in financing the education sector, as well as in determining the fundamental principles of the educational process, the details of the curriculum at all levels of education, the organization of the procedure for receiving teachers, determining the content, recruitment teachers who become public officers, ensuring their continuing education; recruiting and training inspectors responsible for quality control of the education system; funding public education and subsidizing "private schools under contract". The article focuses on the constant attention of the state to the problems of education. It highlights the openness of the French system of higher education and its accessibility for most of the population. The features of France's higher education management system and the specifics of its legislative framework have been disclosed. Four Legislative Acts of the Ministry of Education are characterized, played an important role in its functioning. A more democratic and collegial management of universities for today has been noted. The relevance of the study of the structure and legislative framework of university education in France has been grounded. The types of higher education institutions in France and their features in the context of development trends have been investigated. The current stage of development of the system of French university education and the features of structural transformations have been considered. The features of the functioning of universities, "grand schools" and private higher education institutions have been disclosed. The article draws attention to the achievement of the French system of higher education and its uniqueness. The role and place of large schools in the system of higher education in France have been highlighted. Leading elite schools and universities 
have been mentioned, as well as the conditions for entering them. Attention was paid to the almost equal quality of education in the capital and in the province.

Key words: university, higher school, higher education, university education, management of higher education, legislation, legal framework.

(C) Alla Durdas, 2019

\section{INTRODUCTION}

In today's world, France as one of the initiators of the Bologna Process is seen as a reference pattern of European culture where higher education holds a significant place in the national educational space. French modern higher education system is considered one of the most attractive and advanced in many countries of the world, including Ukraine. The French higher education system is characterized by a large variety of educational institutions with strong traditions which, first of all, can be clearly guided in the preparation of specialists for the requirements of today (Guz \& Mandryck, 2015).

The achievements of the education of France attract the attention of many domestic scientists: O. Alekseyeva, O. Bazhanovska, O. Bocharova, M. Zveryeva, O. Matiyenko, V. Poltavets, L. Shapovalova, O. Avksentyeva, G. Leshchuk, L. Zyazyun, O. Golotyuk, V. Lashchykhina, O. Romanenko. L. Kaminska, N. Lavrychenko, V. Lashchykhina, A. Maksymenko, O. Matviyenko, O. Ovcharuk, O. Permyakova, L. Pukhovska, O. Romanenko, A. Sbruyeva, O. Sukhomlynska, T. Kharchenko.

The peculiarities of the French education system and the formation of its content were considered by such French researchers as P. Bourdieu, A. Leery, L. Legrand, D. Galbo, E. Moren, J. Maggio, S. Frene, S. Forrestier; the issues of the historical development and current state of the French education were investigated by $\mathrm{A}$. Michel, L. Cro, M. Minder, F. Dube, M. Durie-Bell, F. Rope, J.-M. Domenas, A. Shervel, F. Gonaire, A. de La Garanderi, J. Milare, K. Fotin and others.

The problems of legal regulation of higher education modification in the European Union is discussed in the following contexts: development of legal framework in the European Higher Education Area (Mospan, 2014), legal aspect in students' education and training (Mospan, $2016 \mathrm{~b}$, c), legal regulation of higher education and labour market in the EU Member State (Mospan, 2016 a).

The purpose of the article is to investigate the features of the structure and legal framework of the French higher education.

\section{THE STRUCTURE OF FRENCH EDUCATION SYSTEM}

The basic principles of the education system in France have a hundred-year history and were laid down in the 1880-90s. Education is mostly free and it has no religious content and is compulsory for children from 6 to 16 years old. In France, private and public education systems coexist. About $20 \%$ of all students in France study in private schools. The state approves all school programs 
for private and public schools and organizes competitions and exams. Only the state has the right to issue diplomas up to the level of a bachelor.

The higher education system of France is distinguished by a large number of educational institutions with different ultimate goals, different structures and conditions of enrolment. In this regard, we note that the quality, diversity, specificity of educational institutions makes their classification difficult. In France, there are 80 universities (fr. universités) and about 300 higher schools (fr. grandes écoles). French universities differ in size, but in general, regardless of location, they guarantee high quality education. Small universities are characterized by a variety of disciplines and a large number of students in the first cycle of study. Universities of large provincial cities Lille, Toulouse, Lyon, Aix-en-Provis, Bordeaux, Grenoble - as a rule, are distinguished by a narrower specialization, they have more students of the second and third cycles. In the Paris district where a quarter of all French students are concentrated you can find almost anything - any faculty, program or specialization.

Universities are associations of units of training and searching (fr. UFR = Unites $\mathrm{dc}$ formation et de recheche) in the main disciplines led by selected directors as well as institutions and schools more familiar to us (technological, political or legal studios, professionalized, teacher training, general administration or management, tourism, communications, the press, social and economic development, international relations and many others). It is not surprising that only universities assign more than ten different qualifications (Foreign higher education system, 2017, p.45).

A part of higher education is almost completely open (mainly universities) and the introduction is reduced to a simple entry to study and payment of a symbolic amount for the expenses of the office, the other is "closed" (nonuniversity institutions dominate) so admission is done via a strict selection with several applicants for one place. Studying in the last class of the lyceum ("terminal") the student can turn to its council with a request to solve the issue of joining such institutions with selective enrolment based on 47 submissions:

- preparatory classes that are intensively preparing to enter higher education are popular in France through a tough competition (or Grand) Schools;

- University technological institute, in order to receive a technological diploma in two years, is first of all a professional qualification that is beneficial for success in the labour market;

- sections of higher technicians, with an exit in two years to the certificate of "higher technician";

- specialized (higher) vocational schools. To enroll in universities, it is necessary to have a document on secondary education (12 or 13 years of study) which in France is called "undergraduate" and is obtained after compiling a set of final exams held simultaneously throughout the country.

The data about these exams (including student results) is published in press. Individuals without a bachelor's degree can obtain a pass to higher education by passing exams for a diploma of access to higher education (DAEU), which is recognized as an equivalent substitute. DAEU has only two versions: A - humanitarian, B natural and other specialties (Foreign higher education system, 2017, p.46). 


\section{FRENCH HIGHER EDUCATION LEGISLATIVE FRAMEWORK}

Since the adoption of the Debreu Act of 1959 the private education receives assistance from the state (fr. contrat d'association) - it is the state that pays for the work of teachers and participates in the cost of training ( 8 out of 9 educational institutions use this help) (Foreign higher education system, 2017, p.45).

In France, the Ministry of National Education is responsible for educational policy (Ministère de l'Éducation nationale, de la Jeunesse et de la Vie associative). However, the activities of higher education institutions are evaluated by the National Expert Committee, which was established by the law on higher education and has existed since 1984. The main task of this committee is to evaluate the activities of higher education institutions. This national body for the control and management of the quality of higher education is subordinate only to the President and does not depend on any management structures. The Expert Committee regularly collects information on the activities of higher education institutions and annually sends a report to the President on their work and on the state of affairs in the field of higher education. It is important that in France the results of university examinations and assessments are widely published and make it possible not only for the state but for society to judge the academic level of a higher educational institution. This mechanism reflects the historically established centralized system of the French higher education.

In addition, the French Ministry of Education conducts tight control over the activities of universities. Any new course requires verification and accreditation by the ministry. Moreover, accreditation is granted for four years. There is a special council for evaluating educational programs, subordinate to the Ministry of Education, which monitors the quality of students' training. At each faculty there is a list of courses or disciplines, which are compulsory for students. Freedom of choice includes two aspects: the student's choice between theoretical and applied aspects and the teacher's choice of teaching method. Academic freedom implies freedom of choice of educational institutions, disciplines and courses. 500 academic hours are allocated for the study of subjects that give the right to receive a postgraduate diploma of a license or a master-teacher, of which 350 are compulsory subjects (Zlobin, 2004, p.88).

The higher education system of France is organized according to the single European principle (LMD) and is based on the number of years allocated to education after graduating from high school. Thus, three years of study at a university allow obtaining a degree in licenses (180 ECTS credits), five years of study at a university allow obtaining a master's degree (300 credits of ECTS) and eight years of study allow achieving a doctorate $(\mathrm{PhD})$. The degrees of the licensee, master and doctor are the main stages of study in the higher education system.

An analysis of the current state of education in France indicates the constant attention of the state to the problems of education. After the Sorbonne Conference in 1998 the measures introduced in France were aimed primarily at developing a common European-level structure, at one time it was called "3-5-8" or LMD (license - master-doctor - licensee-master-doctor) 
In France, four Legislative Acts of the Ministry of Education were published:

1. The Decree defining the principles of the European scientific and educational space. It introduces a system of credits and emphasizes the creation of a system of educational offers organized in flexible educational cycles of education. It provides each minister with the opportunity to apply these general principles in accordance with the education sectors within his competence [5, p.70-74].

2. The Decree which modernizes the public sector as a whole brings the legal concepts of degree, title and state diploma into line recognizing, in particular, any public diploma issued under state control. It establishes the general principle of state periodic assessment (control) and lastly, it instructs the Minister for Higher Education to ensure the unity of the French educational system (Zyazyun, 2001).

3 , 4. The two other Decrees relate to generalized accounting in the training of students' previous achievements related to their study abroad or is the result of their professional activity. In this way, they determine the conditions for admission, which allows to optimize the stages of training and to formulate the general principles of primary and continuing education (Zyazyun, 2001, p.72).

For the past six years, French higher education institutions have been working to find a model of their functioning that better integrates the main goals of the Bologna process. As a result, a new LMD system of educational levels was adopted (license-master-doctor-license-master-doctor) and it was integrated into the European Union credit system ECTS. It was created a new diploma that is a specialized license, scholarships to support student mobility and to promote international initiatives of higher education institutions were introduced.

All higher education institutions and most of the courses are structured into three study cycles (Bachelor, Master and Doctorate degree) and based on ECTS credits in compliance with the Bologna Process principles.

The French education system is characterized by a strong central state presence in the organization and financing of education. The French education system is regulated by the Department of National Education, Higher Education and Research. Its management is carried out within the framework defined by the parliament, which sets out the basic principles of education. The state plays an important role in governance, since, according to old traditions, the French education system is centralized. The state determines the details of curricula at all levels of education; it organizes the procedure for the reception of teachers, determines the content, recruit teachers who become public servants and provides them with further training; it recruits and trains inspectors responsible for quality control of the education system. It is the main funding agency for the public education system and subsidizes private contracted schools, which are received by approximately $20 \%$ of students.

However, at thelocallevel and since the beginning of the process of decentralization of competences in the management of the educational system in the 1980s, local authorities have played an increasing role in management ensuring the material functioning of the system (construction and maintenance of school buildings, school transport, supply of educational materials, etc.). The official language of instruction 
is French. Public education is secular and free (Key features of the Education System).

Higher education (ISCED 5 - ISCED 8) is distributed in higher education institutions. These institutions have a wide range of legal statuses listed in the French code of education. There are two types of short study cycles (Sections de Techniciens Supérieurs and Diplôme Universitaire Technologique). Courses in French higher education institutions have different goals and conditions for entry but most of them consist of three cycles of study (bachelor's degree, master's and doctor's degrees) and ECTS credits in accordance with the principles of the Bologna process.

Public higher education covers all post-secondary education courses. It corresponds to the general tasks of raising the scientific, cultural and professional levels of the French nation and the people it forms, whose main problems are reducing social inequality, gender equality, developing research and, finally, building the European Higher Education and Research Space (Law No. 2013 - 660 of July 22, 2013 on Higher Education and Research (ESR) revises the policy and management of higher education and research in France. An employment policy in the light of economic, social, environmental and cultural needs is involved in the promotion and distribution of French-speaking world in addition to increased interaction between science and society.

All higher education institutions and most of the courses they offer consist of three study cycles (bachelor, master and doctoral degrees) and based on ECTS credits in accordance with the principles of the Bologna process.

Management of the system is ensured by contractual policies and established by the state with institutions that have administrative and budget autonomy. The policy has undergone significant development in recent years, influenced by the law of August 10, 2007, concerning the freedoms and duties of universities, the LRU law or the Pécresse law in addition to the promulgation of the Law on Higher Education and Research (EPR) in 2013.

Higher education services - System Governance - (PRES - centres for higher education and research) were created in 2006 by the Planning Act No. 2006-450 of April 18, 2006 to offer a more understandable research system and better adapt to the regions of need. They allowed initiating local policies in France and pursuing a policy of pooling the resources and activities of universities, Grandes Écoles and research organizations.

Moreover, university management has become more democratic and more collegial. A new independent administrative body has been created to evaluate institutions, research units and courses. This is the Higher Council for the Evaluation of Research and Higher Education which replaces the Agency for the Evaluation and Registration of Higher Education (Agency for the Evaluation and Assessment of Higher Education). The law also replaces the Conseil Scientifique (COP Scientific Council) and the Committee on Education and Training (CFVU Council on Research and Student Life) in the Conseil académique (Academic Council). Now this body is responsible for the consideration of individual issues relating to the recruitment, placement and career of scientific and teaching staff. 
A year after the adoption of the law, it led to real progress, including (Key features of the Education System):

- improving the mechanisms of career orientation, the transition from directed to the chosen career;

- simplification of the range of training courses to make them more accessible and understandable for young people, families, employers and international students;

- the introduction of the FUN platform, Numérique French University, the opening of 98 MOOC (mass open online courses) as of March 6, 2015;

- improved recognition of gender equality;

- the creation of Pôles Étudiants pour l'Innovation, Le Transfert et l'Entrepreneuriat (PEPITE - Student Clusters for Innovation, Transfer and Entrepreneurship);

- $\quad$ simplification of intellectual property;

- July 22, 2014, two thirds of decrees on the implementation of the EPR Law were published. Last third awaiting State Council approval.

\section{CONCLUSIONS}

Thus, the French higher education system is characterized by the presence of a pronounced national specificity: its own system of diplomas and academic degrees, a special distribution in cycles and a special attitude to diplomas of state educational institutions (they are much more prestigious than diplomas of private universities and schools). The French higher education system is characterized by a wide variety of educational institutions with strong traditions that is, first, capable of clearly orienting themselves in the training of specialists to the requirements of the present. Remaining accessible to the population as relatively "cheap" and transparent the French higher education is marked by a successful system of current and final control of knowledge, the exercise of the right of equal access of individuals to all stages of education and a high level of knowledge and skills of graduates. All of the above components claim a deep analysis and more detailed study in the future.

\section{REFERENCES}

Foreign higher education system: study. Manual (2017). Ed. M.I. Gagarin. Uman (in Ukrainian)

Guz, O.P., \& Mandryck, I. P. (2015). The system of modern higher education in France. (in Ukrainian). http://esnuir.eenu.edu.ua/bitstream/123456789/12200/1/Guz_ Mandryk_veshchs_osvita_Francii.pdf

Key features of the Education System. Eurydice. https:/eacea.ec.europa.eu/ national-policies/eurydice/content/france_en 
Mospan, N. (2014). European Higher Education Area Development: Legal Aspect. Educology, 3, 65-70 (in Ukrainian). https://doi.org/10.28925/22263012.2014.3.6569

Mospan, N. (2016 a). Legal Regulation of Higher Education and Labour Market in the EU Member States.Continuing Proffecional Education: Theory and Practice, 3-4 (48-49), 75-79. http://npo.kubg.edu.ua/article/view/182435/182342

Mospan, N. (2016 b). Students training tendency in the European Union: legal aspect. Pedagogical Process: Theory and Practice, 4 (55), 57-62. https://doi. org/10.28925/2078-1687.2016.4.5761

Mospan N. (2016 c). Students training tendency in the EU and Ukraine: legal aspect. The Morden Higher Education Review, 1. 115-120. http://edreview.kubg.edu.ua/ index.php/edreview/article/view/17

Zlobin, Ye.V., et. al. (2004). Quality Management in an Educational Organization. Tambov, Chapter 1.3. Foreign experience (in Russian). http://ibib.ltd.ua/ zarubejnyiy-opyit-upravleniya-kachestvom.html

Zyazyun, L. (2001). The educational system of France. Native School, 11, 70-74 (in Ukrainian)

\section{УНІВЕРСИТЕТСЬКА ОСВІТА У ФРАНЦУЗЬКІЙ РЕСПУБЛІЦІ: СТРУКТУРА ТА ЗАКОНОДАВЧА БАЗА}

Дурдас Алла, аспірант кафедри теорії та історії педагогіки Педагогічного інституту, Київський університет імені Бориса Грінченка, вул. Тимошенко, 13-б, 04212 Київ, Україна, a.durdas@kubg.edu.ua

У статті розглянуто структурні особливості вищої освіти у Франціï, iі складну й багатоступеневу систему. Звернено увагу на роль держави усфері вищої освіти Франції. Зазначено важливість розвитку освіти для національного розвитку країни та иивілізації в цілому. Зазначається сильна централізована присутність та роль держави у сбері освіти Франції, зокрема в організаціїнавчального процесу та у фінансуванні сфери освіти, а також у визначенні фундаментальних принципів освітнього процесу, деталей навчальних програм на всіх рівнях освіти, організачї процедури прийому вчителів, визначенні змісту, наборі вчителів, які стають державними службовиями, забезпеченні їх підвищення квалібікаціі; наборі та навчанні інспекторів, відповідальних за контроль якості системи освіти; фінансуванні системи державної освіти і субсидуванні "приватні школи за контрактом". У статті акцентовано на постійній увазі держави до освітянських проблем. Йдеться про відкритість франиузької системи вищої освіти та ї̈ доступність для більшої частини населення. Розкрито особливості системи управління вищою освітою Франиії та специфіку ї законодавчої бази. Охарактеризовано чотири законодавчі акти міністерства освіти, які відіграли важливу роль у ї̈ функиіонуванні. Зазначається більш демократичне і колегіальне управління університетами 
на сьогоднішній день. Облрунтовано актуальність дослідження структури та законодавчої бази університетської освіти Франиіі. Досліджено типи вищих навчальних закладів у Франиї та іх особливості в контексті тенденцій розвитку. Розглянуто сучасний етап розвитку системи франиузвкої університетської освіти та особливості структурних перетворень. Розкрито особливості функиіонування університетів, "великих шкіл» та приватних закладів вищої освіти. У статті звертається увага на досягнення франиузької системи вищої освіти та ії унікальність. Виділено роль і місие великих шкіл у системі вищої освіти у Франиї. Згадуються провідні елітні школи та університети, а також зазначено умови вступу до них. Увага приділялася практично рівній якості освіти в столиці і в провінціі.

Ключові слова: університет, вищза школа, вища освіта, університетська освіта, навчальний цикл, управління вищою освітою, законодавство, законодавча база.

Accepted: 25.11.2019

Received: 12.12.2019 